\title{
Pelaksanaan Program Broadband Learning Center (BLC) Oleh Dinas Kominfo Pemkot Surabaya Untuk Mewujudkan Surabaya Cyber City
}

\author{
Eka Maria Ulfa* \\ eka_maria0158@yahoo.com
}

\begin{abstract}
Abstrak
Dinas Kominfo Pemkot Surabaya merupakan instansi pemerintah di bidang IT yang mencoba memfasilitasi segala kebutuhan IT warganya agar dapat melek IT sekaligus diharapkan mampu memproduksi konten informasi, sehingga dapat berkontribusi dalam pembangunan kota Surabaya. Sampai saat ini, Dinas Kominfo Pemkot Surabaya telah menyediakan fasilitas internet gratis di 42 titik taman kota di Surabaya yang bisa diakses warga selama 24 jam. Tujuannya agar masyarakat kota Surabaya lebih mudah untuk memperoleh beragam informasi secara online. Akan tetapi, dari fasilitas akses internet tersebut masih belum dimanfaatkan masyarakat secara maksimal. Sehingga masih terjadi kesenjangan digital (digital divide) di kota Surabaya. Oleh karena itu, dibentuklah program pelatihan internet yaitu Broadband Learning tentang Teknologi Informasi dan Komunikasi bagi warga Surabaya agar melek IT secara keseluruhan. Pada akhirnya, penerapan konsep Surabaya Cyber City dapat meningkatkan kualitas kinerja Pemkot Surabaya yang berbasis e-Goverment. Metode analisis dalam penelitian ini adalah deskriptif kualitatifuntuk menggambarkan fenomena yang terjadi berkaitan dengan pelaksanaan program BLCperiode tahun 2014-2015. Penelitian ini menggunakan metode studi kasus dengan teknik penjodohan pola, yakni membandingkan pola berdasarkan data empiris dengan pola yang diprediksikan. Teknik pengambilan data menggunakan Focus Group Discussion (FGD), wawancara, observasi langsung dan dokumentasi.
\end{abstract}

Kata Kunci: cyber city, e-government,, ICT Learning Center, literasi internet

\begin{abstract}
Communication and Informatics (Kominfo) Department of Surabaya City Government is a government agency in the field of IT trying to facilitate all the needs of its citizens in order to be literate for IT and all at once is expected to produce content for information, so that it can contribute in the development of the city of Surabaya. They has been providing a free internet facilities at 42 points the City Park in Surabaya citizens which can be accessed for 24 hours. Therefore, the internet training program, namely Broadband Learning Center (BLC) were built. That is a form of learning internet literacy program of diverse material about ICT for the citizens of Surabaya become IT literacy. The application of the concept of Surabaya Cyber City can improve the quality of Surabaya city government performance for eGovernment based.In this study, the method of analysis used is descriptive qualitative research methods, to describe a phenomenon that occurred with regard to the implementation of the program BLC in period of 2014-2015. This research method using case studies by comparing the pattern based empirical data with the predicted pattern. Technique of data retrieval using Focus Group Discussion, interviews, direct observation and documentation.
\end{abstract}

Keyword: cybercity, e-government, internet literacy, ICT Learning Center.

\footnotetext{
${ }^{*}$ Korespondensi : Eka Maria Ulfa Dinas Kominfo Kabupaten Pasuruan, Jl Hayam Wuruk No 14 Pasuruan 67115, Telpon/ Fax: 0343-429064
} 


\section{Pendahuluan}

Di era keterbukaan informasi publik yang telah menjadi kebutuhan utama masyarakat, pemerintah semakin dituntut untuk lebih memaksimalkan peran dan fungsinya sebagai pelayan publik. Dinas Komunikasi dan Informatika (Kominfo) tidak hanya sekedar tampil sebagai tim perancang beragam perangkat Teknologi Informasi Komunikasi dan komunikator penyampai pesan dari berbagai kebijakan pemerintah saja. Akan tetapi juga harus menjalankan peran gandanya sebagai humas pemerintah serta menciptakan masyarakat melek IT yang juga mampu memproduksi informasi. Melalui new media, peran dan fungsi Dinas Kominfo dalam mempublikasikan program e-government sekaligus untuk meningkatkan kualitas pelayanan kepada masyarakat. Dinas Kominfo Pemkot Surabaya merupakan instansi pemerintah di bidang IT yang mencoba memfasilitasi segala kebutuhan IT warganya agar dapat melek IT sekaligus diharapkan mampu memproduksi konten informasi, sehingga dapat berkontribusi dalam pembangunan kota Surabaya.

Sampai saat ini, Dinas Kominfo Pemkot Surabaya telah menyediakan fasilitas internet gratis di 42 titik taman kota di Surabaya yang bisa diakses warga selama 24 jam. Diantara titik hot spot yang bisa dimanfaatkan yaitu di Taman Bungkul yang berlokasi di Jl Raya Darmo. Tujuannya agar masyarakat kota Surabaya lebih mudah untuk memperoleh beragam informasi secara online. Dari fasilitas akses internet tidak berbayar yang disediakan tersebut masih belum dimanfaatkan masyarakat secara maksimal. Hal ini karena jumlah pengguna internet di kota Surabaya saat ini masih di kisaran 2 juta orang, dari total jumlah penduduk kota Surabaya mencapai 2,9 juta orang. Sehingga masih terjadi kesenjangan digital (digital divide) di kota Surabaya. Oleh karena itu, dibentuklah program pelatihan internet yaitu Broadband Learning Center (BLC) yang merupakan program literasi internet berupa pembelajaran beragam materi tentang Teknologi Informasi dan Komunikasi (TIK) bagi warga Surabaya yang diberikan secara gratis dan bersertifikat, dilengkapi dengan berbagai fasilitas pendukung yang juga dapat dimanfaatkan pengunjung untuk menggunakan fasilitas internet serta free wifi.

Tujuan utama dari penerapan program BLC ini adalah agar warga Surabaya tidak gagap teknologi (gaptek) di era serba digital. Hal ini sekaligus sebagai upaya dari Dinas Kominfo Pemkot Surabaya dalam menyiapkan warga Surabaya 
untuk siap berkompetisi dengan negara-negara ASEAN. Warga Surabaya diharapkan akan menjadi warga yang paling siap untuk menyongsong era Masyarakat Ekonomi ASEAN (MEA) yang rencananya akan segera diberlakukan pada akhir 2015 mendatang. Ketika nantinya MEA mulai diberlakukan, artinya negara-negara seASEAN akan bisa bebas berinvestasi di Indonesia, termasuk di Surabaya. Sehingga dengan pelatihan TIK yang dapat diakses secara gratis di BLC, masyarakat kota Surabaya diharapkan sudah mempunyai bekal untuk bersaing dengan masyarakat global sekaligus siap menjadi tuan di kotanya sendiri.

Melalui BLC, semua lapisan masyarakat Surabaya berkesempatan bisa belajar beragam materi pelatihan TIK tanpa ada pungutan. Bekerjasama dengan PT Telkom Divisi Regional V Jawa Timur, BLC berupaya meningkatkan pelayanannya agar dapat menjangkau seluruh masyarakat Surabaya sebagai upaya percepatan menuju Surabaya Cyber City. Yaitu konsep kota modern berbasis teknologi informasi yang saat ini telah banyak diterapkan di sejumlah kota besar di seluruh dunia, sebagai konsekuensi logis dari meningkatnya kebutuhan masyarakat yang ingin mengakses informasi dan berkomunikasi dengan mudah dan cepat.

Dari aplikasi keseluruhan program BLC oleh Dinas Kominfo Pemkot Surabaya tersebut tentunya masih harus dilakukan up grade dari segala lini, sehingga mampu menjawab tantangan kebutuhan literasi IT bagi semua warga Surabaya dalam mewujudkan masyarakat melek teknologi informasi dan komunikasi. Yang perlu digarisbawahi adalah, bagaimanakah pelaksanaan program BLC agar dapat dimanfaatkan oleh semua warga Surabaya? Lalu bagaimana pola manajemen komunikasi Dinas Kominfo Pemkot Surabaya untuk meningkatkan kualitas jajarannya dalam menyelenggarakan program pelatihan TIK? Tidak hanya akan berimplikasi pada terwujudnya Surabaya Cyber City, melainkan juga mengoptimalkan pelaksanaan sistem pemerintahan berbasis e-Government yang jauh berkualitas dan berdaya saing secara internasional.

Berdasarkan latar belakang diatas maka rumusan masalah yang akan dibahas di dalam penelitian ini adalahbagaimana pelaksanaan program Broadband Learning Center (BLC) oleh Dinas Kominfo Pemkot Surabaya periode 2014-2015. Tujuan penelitian ini adalah untuk mengetahui tentang pelaksanaan program Broadband Learning Center (BLC) oleh Dinas Kominfo Pemkot Surabaya periode 2014- 
2015 dari perspektif komunikasi sekaligus memahami pelaksanaan Digital Government Service (DGS) berbasis e-Government oleh Dinas Kominfo Pemkot Surabaya.

\section{Metode Penelitian}

Penelitian ini dilakukan di kantor Dinas Komunikasi dan Informatika (Kominfo) Pemerintah Kota (Pemkot) Surabaya yang berlokasi di Jalan Jimerto No 25-27 Lt V Surabaya. Berdasarkan kerangka pemikiran diatas, maka dapat digambarkan model penelitian yang menjelaskan tentang pelaksanaan program Broadband Learning Center (BLC) oleh Dinas Kominfo Pemkot Surabaya dalam mewujudkan Surabaya Cyber City.Jenis penelitian ini adalah deskriptif kualitatif. Sifat deskriptif diarahkan untuk menggambarkan fenomena yang terjadi berkaitan dengan pelaksanaan program Broadband Learning Center (BLC)oleh Dinas Kominfo Pemkot Surabaya untuk mewujudkan masyarakat Surabaya Cyber City. Penelitian ini menggunakan metode studi kasus. Penelitian ini menggunakan studi kasus (Wimmer, 2000: 110; Kriyantono, 2006: 95), yaitu dilakukan dengan teknikFocus Group Discussion (FGD), wawancara, observasi langsung, dan dokumentasi

\section{Hasil dan Pembahasan}

Berdasarkan penelitian yang dilakukan tentang pelaksanaan program BLC oleh Dinas Kominfo Pemkot Surabaya selama 2014-2015, maka diperoleh hasil temuan yang disesuaikan dengan uraian alur desain penelitian pada bab sebelumnya.Dalam proses pelatihan TIK, Dinas Kominfo Pemkot Surabaya mengacu pada perencanaan program literasi TIK bagi seluruh warga kota Surabaya, terutama mereka yang masih belum melek internet. Dengan demikian, ada panduan teknis pelaksanaan literasi internet yang harus dipatuhi oleh Dinas Kominfo Pemkot Surabaya. Harapannya, semua program pelatihan TIK yang telah dirancang dapat dilaksanakan dengan hasil maksimal dan tepat sasaran sesuai dengan yang ditargetkan sebelumnya.

Berdasarkan kategori, mayoritas pengunjung BLC selama tahun 2015 didominasi oleh siswa SD, kemudian disusul oleh Bunda PAUD dan ibu rumah tangga. Materi TIK yang diajarkan seputar Internet, Office dan Desain, masing-masing terbagi dalam 22 kali pertemuan dibawah pengajaran instruktur BLC. Sedangkan dari 
segi pengawasan atas pelaksanaan program secara keseluruhan langsung dipantau oleh Dinas Kominfo Pemkot Surabaya.

Mengacu pada hasil perbandingan jumlah pengunjung dan peserta program BLC tersebut dapat diketahui bahwa minat masyarakat kota Surabaya untuk mempelajari TIK di BLC semakin meningkat setiap tahunnya. Dengan antusiasme semangat belajar yang dimiliki peserta pelatihan tersebut maka dapat disimpulkan jika mereka memiliki ICT Awareness yang cukup tinggi untuk mempelajari materi TIK. Tidak hanya diisi oleh masyarakat yang masih berusia produktif atau berstatus sebagai pelajar saja, tetapi juga mereka yang sudah berusia diatas 50 tahun. Misalnya yang terpantau di BLC Taman Prestasi di Jl Gentengkali Surabaya, khususnya di periode pelatihan pada bulan Maret 2015 untuk materi internet, blog dan social network. Ratarata mereka terdiri dari ibu rumah tangga dan Bunda PAUD, berusia antara 38 sampai 70 tahun.

Dalam sesi pelatihan TIK, masing-masing BLC yang tersebar di 23 titik lokasi di kota Surabaya dikelola oleh 2 trainer di masing-masing BLC. Total ada 46 trainer di 23 titik BLC yang tersebar di kota Surabaya. Mereka terdiri dari tenaga ahli/ expert di bidang IT dengan masing-masing klasifikasi keahlian \& penguasaan di bidang komputer dan informatika yang ditempatkan di seluruh BLC.

Dari segi penyediaan infrastruktur, program pelatihan TIK di BLC didukung oleh Telkom Divre V Jawa Timur melalui program Corporate Social Responsibility (CSR)-nya. Sesuai dengan kesepakatan dalam MoU, Telkom menyediakan semua infrastruktur yang dibutuhkan, mulai dari jaringan koneksi internet, infrastruktur seperti komputer dan peralatan IT pendukungnya, sampai pada penyediaan instrukturnya. Tetapi hal tersebut dilakukan sampai pada bulan Desember 2014 saja. Mulai Januari 2015 sampai seterusnya, semua kebutuhan program BLC terutama dari segi penyediaan instruktur TIK telah diambil alih oleh Dinas Kominfo Pemkot Surabaya.

Sampai bulan April 2015, jumlah total instruktur BLC yang tersebar di 23 titik BLC di kota Surabaya ada 46 orang. Dengan rincian, masing-masing BLC terdapat 2 orang instruktur yang memberikan pelatihan TIK secara intensif kepada seluruh peserta, sesuai dengan materi yang telah diprogramkan. Masing-masing sesi pelatihan berdurasi sekitar dua jam. Mayoritas tenaga pengajar yang direkrut oleh 
Dinas Kominfo adalah lulusan S1 atau D4 dengan latar belakang pendidikan jurusan komputer, informatika dan sebidangnya yang memahami konsep pengajaran dan mengikuti perkembangan teknologi informasi.

Dalam aplikasinya di lapangan, setiap BLC menyediakan beragam materi pengajaran dengan menu pelatihan TIK yang berbeda. Semuanya disesuaikan dengan mapping segmentasi \& kebutuhan dari peserta pelatihan yang telah disinkronkan dengan tren teknologi informasi yang sedang berkembang saat ini. Pada setiap sesi pelatihan di BLC, ada pembagian materi dijadikan satu yaitu untuk Pengenalan Dasar (Optional) dan tiga materi utama yaitu Aplikasi Perkantoran, Desain Grafis dan Bisnis Online. Pelatihan Pengenalan Dasar diberikan kepada peserta yang sama sekali tidak mengetahui cara penggunaan komputer.

Pada setiap sesi pelatihan di BLC, ada pembagian materi dijadikan satu yaitu untuk Pengenalan Dasar (Optional) dan tiga materi utama yaitu Aplikasi Perkantoran, Desain Grafis dan Bisnis Online. Pelatihan Pengenalan Dasar diberikan kepada peserta yang sama sekali tidak mengetahui cara penggunaan komputer. Pada materi pengenalan dasar ini diajarkan bagaimana cara menyalakan dan mematikan komputer, menggunakan mouse dan keyboard. Selanjutnya bagi peserta yang sudah menguasai penggunaan dasar komputer dan bagi peserta yang pada awalnya belum menguasai dasar penggunaan komputer tapi sudah melewati tahap pelatihan optional, dipersilahkan untuk memilih salah satu materi dari tiga materi utama. Setelah memilih salah satu materi peserta diwajibkan mengikuti pre test yang bertujuan untuk mengetahui sejauh mana kemampuan peserta.

Berdasarkan hasil laporan pelaksanaan program pelatihan TIK yang telah dilaksanakan oleh BLC pada tahun 2014 diketahui bahwa dari tiga materi yang diberikan, sebanyak 15.417 orang peserta lebih berminat untuk mempelajari materi Aplikasi Perkantoran daripada materi Bisnis Online. Hal itu ditunjukkan oleh jumlah peserta Bisnis Online yang hanya 3.438 orang peserta, sedangkan materi Desain Grafis sebanyak 2.495 orang peserta. Materi Aplikasi Perkantoran paling banyak diminati oleh Pelajar SD sebanyak 7.117 orang peserta, Bunda PAUD sebanyak 2.397 orang peserta dan Karyawan Swasta sebanyak 1.266 orang peserta. Pada materi Desain Grafis peminat paling banyak berasal dari kategori Bunda PAUD sebanyak 473 orang peserta, Karyawan Swasta sebanyak 385 orang peserta dan Pelajar SLTA sebanyak 
307 orang peserta. Pada materi Bisnis Online paling banyak peminatnya berasal dari kategori Pelajar SLTP sebanyak 768 orang peserta, PNS sebanyak 437 orang peserta dan UKM sebanyak 381 orang peserta.

\section{Permasalahan Internal}

\section{Kurang Maksimalnya Sosialisasi Tentang BLC}

Sebagian masyarakat menilai jika program pelatihan TIK yang bertujuan agar menjadikan seluruh warga kota Surabaya melek IT tersebut masih kurang maksimal dari segi publikasi, sehingga promosi tentang BLC masih kurang gencar. Indikasinya dilihat dari masih banyaknya warga yang belum mengetahui tentang program BLC yang sebenarnya sudah ada sejak tahun 2009 lalu. Padahal seharusnya, fasilitas pelatihan TIK yang ditujukan bagi terwujudnya literasi internet masyarakat kota Surabaya tersebut wajib diketahui oleh semua lapisan masyarakat, tanpa terkecuali. Apalagi saat ini jumlah titik-titik lokasi BLC semakin bertambah dengan total ada 23 BLC yang tersebar di ruang-ruang publik kota Surabaya. Sehingga harus diimbangi dengan gencarnya kegiatan sosialisasi tentang keberadaan BLC kepada publik.

Sudjono, usia 50 tahun, diantara peserta pelatihan TIK di BLC Taman Prestasi mengakui jika selama ini memang sudah ada upaya sosialisasi yang telah dilakukan oleh Dinas Kominfo Pemkot Surabaya untuk mempromosikan keberadaan program BLC. Seperti yang disampaikan melalui beberapa kecamatan atau di balaibalai RW. Tetapi hal tersebut masih belum bisa menjangkau semua lapisan masyarakat kota Surabaya yang sangat heterogen dan tersebar di 31 kecamatan. Sehingga hal tersebut berdampak pada masih minimnya referensi pengetahuan masyarakat tentang serba-serbi program BLC. Padahal, bisa jadi banyak diantara mereka yang juga ingin dan berminat untuk belajar pelatihan TIK di BLC. Terutama bagi warga yang sama sekali belum bisa menguasai komputasi

dan internet.

Ketika dijumpai di sesi FGD yang digelar di BLC Taman Prestasi pada tanggal 11 Maret 2015, dia mengatakan bahwa kegiatan publikasi yang dapat dilakukan melalui sosialisasi tentang BLC tersebut sangatlah penting dilakukan oleh Dinas Kominfo Pemkot Surabaya sebagai pengelola program BLC. Terlebih saat ini 
Pemkot Surabaya telah memberlakukan surat-menyurat administrasi secara elektronik sebagai bagian dari pelaksanaan program e-government yang sudah lama diterapkan, dimana hal tersebut melibatkan para perangkat pemerintahan sampai pada level Rukun Warga (RW) dan Rukun Tetangga (RT).

Program yang terbaru yaitu pelibatan semua Ketua RW/ RT dalam penyusunan usulan program serta anggaran Musyawarah Perencanaan Pembangunan (Musrenbang), dimana yang bertugas melakukan entry data tentang usulan pembangunan kota adalah masing-masing Ketua RW/ RT di kota Surabaya.

Dengan pemberian fasilitas internet gratis di setiap kelurahan dan RW/ RT, maka keberadaan BLC sebagai pusat pelatihan TIK bagi seluruh warga kota Surabaya tersebut sudah barang tentu sangat penting untuk diketahui oleh seluruh lapisan masyarakat. Seperti yang dijumpainya pada salah satu Ketua RW di tempat tinggalnya yaitu di kecamatan Rungkut. Dia menceritakan bahwa infrastruktur internet gratis yang telah diberikan oleh Pemkot Surabaya kepada lingkungan RT dan RW-nya selama ini belum bisa dimanfaatkan dengan maksimal dikarenakan Ketua RT dan RW-nya yang ternyata tidak bisa mengoperasikan komputer. Sehingga yang terjadi kemudian adalah, pemberian fasilitas internet gratis tersebut menjadi mangkrak dan kebijakan-kebijakan terbaru dari Pemkot Surabaya pada akhirnya tidak tersampaikan ke masyarakat dengan baik. Padahal tujuan diberikannya akses internet gratis kepada Ketua RT dan Ketua RW tersebut agar mereka dapat memanfaaatkannya untuk membuat laporan tentang kegiatan di masing-masing lingkungannya secara elektronik.

Di sisi lain, keinginan warga kota Surabaya untuk dapat mengikuti pelatihan TIK di BLC, tinggi. Namun karena sosialisasi tentang program BLC tidak masuk sampai pada tingkatan masyarakat dengan strata paling bawah, maka bisa jadi mereka tidak mengetahui keberadaan BLC. Sehingga dengan demikian, program BLC masih belum dapat menjangkau segala lapisan masyarakat kota Surabaya.

\section{Tidak Semua Lokasi BLC Strategis}

Sampai bulan Mei 2015, total ada 23 BLC yang tersebar di ruang publik kota Surabaya. Dari keselurahan titik BLC tersebut ada beberapa diantaranya yang lokasinya kurang strategis untuk dikunjungi masyarakat. Misalnya BLC yang 
bertempat di rusun dan kelurahan-kelurahan. Sudjono warga Rungkut yang merupakan salah satu peserta pelatihan TIK di BLC Taman Prestasi mengatakan, sebagian orang enggan untuk masuk dan memanfaatkan BLC yang lokasinya di rusun (rumah susun) karena mereka merasa kurang nyaman. Hal tersebut dikarenakan fungsi rusun sebagai tempat tinggal padat penduduk. Sehingga otomatis dari segi kenyamanan dan suasana, kurang mendukung jika digunakan sebagai tempat pelatihan TIK yang sangat membutuhkan ketenangan dan konsentrasi.

Sedangkan lokasi BLC yang juga menurutnya kurang strategis untuk dijangkau masyarakat yakni BLC yang lokasinya berada di kantor kecamatan. Pertimbangannya, gedung tersebut merupakan institusi pemerintahan yang identik dengan sifat formal dan hiruk-pikuknya suasana pelayanan pemerintahan yang selalu dipadati masyarakat setiap saat. Sehingga kurang nyaman jika digunakan sebagai tempat pelatihan TIK.

\section{Fasilitas Personal Computer (PC) Yang Kurang Mutakhir}

Keterbatasan spesifikasi PC yang masih menggunakan Core 2 Duo jelas berdampak langsung pada kelancaran instruktur BLC di dalam memberikan beragam materi komputasi dan internet. Ini karena, Core 2 Duo memiliki keterbatasan pada kapasitas memori Random Access Memory (RAM)-nya, dengan rata-rata hanya 2 Giga saja. Sehingga jika PC digunakan untuk membuat aplikasi yang membutuhkan memori agak besar, maka bisa berpengaruh pada kecepatan akses pada masingmasing PC yang ada di BLC. Misalnya untuk materi pelatihan tentang cara pembuatan desain grafis dengan program Inscape.Keterbatasan spefisikasi processor tersebut juga berpengaruh pada terganggunya proses networking yang sedianya akan dilakukan oleh Dinas Kominfo Pemkot Surabaya dengan dunia industri kreatif.

\section{Belum Adanya Pengukuran Terhadap Indeks Kepuasan Masyarakat (IKM)/ Pengguna BLC}

Selama penyelenggaraan program BLC, Dinas Kominfo Pemkot Surabaya belum memiliki data tentang Indeks Kepuasan Masyarakat (IKM), dalam hal ini mereka para pengguna BLC yang menjadi user/ pengguna program pelatihan TIK di BLC. IKM sangat berguna untuk mengevaluasi keberlangsungan pelaksanaan 
program BLC ke depannya agar mencapai target yang telah ditetapkan sebelumnya. Hal itu bisa dilaksanakan melalui survei mencakup data-data dan informasi tentang tingkat kepuasan masyarakat yaitu para peserta pelatihan TIK dan pengunjung di BLC. Hal tersebut diperoleh dari hasil pengukuran, baik secara kuantitatif dan kualitatif atas pendapat mereka dalam memperoleh pelayanan dari instruktur BLC yang berperan sebagai penyelenggara pelayanan publik untuk kemudian dibandingkan antara harapan dan kebutuhannya.

Pelaksanaan IKM digunakan sebagai bahan evaluasi terhadap pelaksanaan program BLC selama ini, sekaligus sebagai upaya untuk meningkatkan kualitas pelayanan publik secara berkelanjutan. Hal ini seperti yang disyaratkan oleh Kementerian Pendayagunaan Aparatur Negara dan reformasi Birokrasi (KemenPAN-RB) yang terangkum dalam Keputusan Menpan No: KEP/25/M.PAN/2/2004 Tentang Pedoman Umum Penyusunan Indeks Kepuasan Masyarakat Unit Pelayanan Instansi Pemerintah. Di dalamnya disebutkan bahwa unsur Survei Kepuasaan Masyarakat adalah faktor dan aspek yang dijadikan pengukuran kepuasan masyarakat terhadap penyelenggaraan pelayanan publik.

\section{Kecepatan Akses Internet Yang Kurang Maksimal}

Sampai saat ini, program BLC sebagai upaya menuju Surabaya Cyber City masih mengalami berbagai kendala teknis. Diantaranya, kendala infrastruktur yang berkaitan dengan program pelatihan TIK yang masih belum dapat memenuhi kebutuhan peserta pelatihan BLC, baik dari segi kualitas maupun kuantitas.

Dari segi kualitas, kecepatan akses internet masih menjadi permasalahan signifikan yang secara otomatis berimplikasi terhadap kelancaran pelaksanaan program pelatihan TIK. Hal ini karena, sampai saat ini kapasitas bandwidth di hampir seluruh BLC yang tersebar di kota Surabaya masih terbatas di angka 1 sampai $2 \mathrm{Mbps}$ yang digunakan untuk rata-rata 10 unit pada masing-masing titik BLC. Minimnya pasokan bandwidth tersebut berdampak pada akses internet yangtidak bisa maksimal ketika proses pembelajaran TIK berlangsung. Terutama pada saat materi internet yang sangat membutuhkan aksesibilitas tinggi. Misalnya, program pelatihan pembuatan $b \log$. 
Dengan kapasitas maksimal hanya 2 Mbps di hampir semua titik BLC yang tersebar di kota Surabaya, semua unit Personal Computer (PC) yang digunakan oleh peserta pelatihan secara bersamaan sudah barang tentu akan mengalami kendala akses internet. Mulai dari turunnya kecepatan aksesbilitas, sampai pada kondisi yang mengakibatkan jaringan internet tiba-tiba error. Seperti yang pernah terjadi di BLC Taman Prestasi, pada sesi pelatihan pembuatan blog yang dilaksanakan pada hari Selasa, 11 Maret 2015. Besarnya kapasitas jaringan internet yang dibutuhkan oleh para peserta pelatihan yang dipergunakan untuk membuat program desain blog pada saat itu tidak sebanding dengan besaran bandwidth yang tersedia. Sehingga tidak hanya berdampak pada lambatnya kecepatan akses internet, tetapi juga jaringan yang tibatiba bank.

\section{Belum Adanya Modul Resmi Untuk Peserta Pelatihan TIK}

Sampai saat ini, proses pengajaran yang dilakukan oleh masing-masing instruktur BLC masih mengandalkan modul yang sifatnya sebatas internal. Artinya, buku panduan materi hanya dimiliki oleh tim BLC saja dan tidak untuk dipublikasikan untuk peserta pelatihan. Sehingga selama pembelajaran TIK dilaksanakan, mereka tidak memiliki buku pegangan yang digunakan sebagai panduan belajar setelah sesi pertemuan di BLC berakhir. Padahal, kepemilikan modul tersebut sangat mendukung peserta pelatihan agar dapat memahami semua materi pelatihan TIK yang diajarkan oleh instruktur BLC di dalam setiap kali pertemuannya.

Selama ini, tim BLC memang telah menyediakan modul secara online yang dapat diunduh masyarakat di website milik BLC, yaitu http://blcsurabaya.wix.com. Akan tetapi, keterbatasan penguasaan komputer dari peserta pelatihan juga yang pada akhirnya membuat pemberian fasilitas modul online tersebut tidak efektif. Sehingga keberadaan modul materi dalam bentuk hard copy atau buku masih sangat dibutuhkan. Menurut Juli, dia telah melaporkan tentang persoalan masih belum tersedianya modul tersebut sebagai bahan laporan bulanan yang disampaikan ke Dinas Kominfo Pemkot Surabaya agar mendapat respon. 


\section{Permasalahan Eksternal}

\section{Keajegan Kehadiran Peserta Pelatihan TIK}

Karena sifat pelatihan TIK di BLC yang tidak berbayar alias gratis serta tidak mengikat, maka ada kecenderungan terjadinya ketidakajegan kehadiran parapeserta pelatihan. Padahal, semuanya sudah terjadwal sampai pada akhir pelaksanaan program, sesuai dengan masing-masing materi yang menjadi satu paket di dalamnya. Menurut Sekretaris Dinas Kominfo Pemkot Surabaya, Cahyono Utomo, dari hasil laporan bulanan yang diterimanya dari keseluruhan instruktur BLC diketahui bahwa selama ini masih banyak peserta pelatihan yang absen dari sesi pelatihan yang seharusnya diikuti secara tuntas sampai berakhirnya materi sesuai dengan materi yang diajarkan. Rata-rata alasan ketidakhadiran mereka yang sebagian besar adalah ibu rumah tangga tersebut dikarenakan terkendala oleh aktifitas yang bersangkutan. Seperti kesibukannya sebagai ibu rumah tangga atau faktor eksternal lainnya. Sehingga berakibat pada ketidakajegan kehadiran peserta di dalam sebuah rombongan belajar.

Program pelatihan TIK yang sifatnya cuma-cuma alias tak berbayar tersebut juga menjadi salah satu faktor penyebab dari sikap inkonsistensi peserta pelatihan untuk tetap menaati sistem kehadiran yang diberlakukan. Karena sifatnya gratis, maka ada kesan menggampangkan absensi. Padahal, tingkat kehadiran merupakan salah satu syarat yang harus dipenuhi oleh semua peserta pelatihan untuk mendapatkan piagam penghargaan atau sertifikat sebagai tanda kelulusan. Idealnya, mereka diwajibkan hadir pada setiap sesi pertemuan secara berturut-turut di dalam satu paket program yang telah dipilih, yaitu selama 22 kali pertemuan. Tetapi pada kenyataannya, banyak diantaranya yang tidak mematuhi aturan.

\section{Masyarakat Masih Belum Familiar Dengan Software Yang Digunakan Dalam Pelatihan TIK}

Sistem operasi komputer dalam pelatihan TIK di BLC menggunakan Linux dengan varian Ubuntu yang bersifat open source yaitu perangkat lunak dimana kode program terbuka dan disediakan oleh pengembangnya secara umum agar dapat dipelajari, diubah atau dikembangkan lebih lanjut dan disebarluaskan. 
Sehingga lebih memudahkan dalam pengoperasian, kemampuan prima, sistem keamanan \&networking yang handal dan terjamin keaslian software-nya. Namun karena sebagian besar masyarakat Surabaya belum begitu mengenal sistem Linux, masyarakat yang telah terbiasa menggunakan Windows sedikit kesulitan ketika harus beradaptasi dalam menggunakannya. Hal ini karena mereka harus mengubah kebiasaan memakai Windows ke Linux. Seperti yang diungkapkan oleh Esthi, diantara peserta pelatihan Tik di BLC Taman Prestasi pada saat FGD digelar pada tanggal 11 Maret 2015.

\section{Analisis Pelaksanaan Program BLC Dalam Perspektif Komunikasi}

Pelaksanaan program BLC oleh Dinas Kominfo Pemkot Surabaya tidak terlepas dari proses komunikasi yang terbangun antara Dinas Kominfo Pemkot Surabaya sebagai pihak penyelenggara program dengan tim BLC, yaitu para instruktur BLC yang bertugas sebagai tim pengajar dalam pelatihan TIK di 23 titik BLC yang ada di kota Surabaya dan peserta pelatihan di BLC.

Dalam pelaksanaannya, Pemkot Surabaya menunjuk Dinas Komunikasi dan Informatika Kota Surabaya bertindak sebagai pihak penyelenggara \& pelaksana program BLC. Bekerjasama dengan PT Telkom Drive V Jawa Timur melalui program Corporate Social Responsibility (CSR) dalam MoU yang telah disepakati, BLC yang membidik warga Surabaya yang belum melek IT. Tim BLC terdiri dari ahli IT yang juga memiliki kemampuan soft skills, yaitu penguasaan terhadap teknik micro teaching atau tata cara pengajaran yang menarik.

Agar kualitas kemampuan atau kapasitas instruktur BLC tetap terjaga dengan baik, maka Dinas Kominfo Pemkot Surabaya memberikan program pelatihan secara intensif. Materinya berupa penguatan terhadap penguasaan computer skills serta pemantapan materi pemrograman terbaru yang disampaikan dalam format outbond.

\section{Literasi Internet}

Sebagai message atau pesan yang disampaikan oleh Dinas Kominfo Pemkot Surabaya serta tim BLC, literasi internet merupakan sebuah ide berupa pesan, informasi, pengetahuan sekaligus berisi ajakan kepada komunikan agar bisa mengoperasikan komputer dan mengakses internet. Atau bahkan sampai pada 
tahapan memproduksi konten new media sebagai bentuk pemberdayaan (empowerment). Tidak hanya menjadikan warga atau orang yang tinggal di kota Surabaya menjadi smart dan melek IT saja, melainkan bagaimana menjadikan kota Surabaya dengan sistem pemerintahan Pemkot Surabaya yang juga smart. Yaitu selalu adaptif dalam menyikapi pesatnya perkembangan teknologi informasi. BLC adalah diantara sarana untuk mewujudkannya.

Ajakan Dinas Kominfo Pemkot Surabaya agar warganya bisa mengakses internet melalui mengikuti pelatihan TIK di BLC tersebut mendapat sambutan positif.Dari hasil rekap data jumlah pengunjung dan peserta pelatihan TIK di 23 BLC pada tahun 2015 (sampai bulan April) diketahui bahwa terjadi peningkatan minat belajar masyarakat kota Surabaya untuk mengikuti program pelatihan TIK di BLC. Hal ini terpantau dari peningkatan jumlah peserta BLC pada tahun 2015 dengan interval waktu yang sama, terhitung mulai bulan Januari sampai April. Jika pada tahun 2014 jumlah peserta pelatihan TIK sebanyak 6.118 orang, maka pada tahun 2015 mencapai 13.100 orang. Dengan demikian, jumlah peserta program BLC pada periode pelatihan TIK di bulan Januari sampai April 2015 jauh meningkat signifikan jika dibandingkan dengan periode yang sama di tahun 2014. Total peningkatan jumlah peserta sampai 6.982 orang atau dengan prosentase kenaikannya sampai seratus persen lebih.

Dengan demikian, ajakan Dinas Kominfo pemkot Surabaya kepada masyarakat Surabaya agar mau belajar internet di BLC selama ini telah mendapatkan feedback atau respon baik. Sehingga secara otomatis, pesan berupa pembekalan literasi internet kepada warga kota Surabaya, terutama bagi mereka yang belum melek IT, dapat tersampaikan dengan baik.

\section{Refleksi Program BLC}

Dari hasil temuan dan analisa pelaksanaan program BLC Pemkot Surabaya yang diselenggarakan oleh Dinas Kominfo Pemkot Surabaya tersebut diketahui bahwa program BLC telah sesuai dengan apa yang ditargetkan oleh Pemkot Surabaya selama ini. Yaitu mewujudkan masyarakat melek IT melalui upaya peningkatan literasi internet yang dilakukan secara berkelanjutan agar dapat 
membentuk masyarakat cerdas (smart city) sebagai modal utama dalam merealisasikan Surabaya Cyber City.

Melalui program BLC, Pemkot Surabaya tidak hanya dapat mewujudkan targetnya sebagai cyber city yang identik dengan masyarakatnya yang cerdas dengan selalu terkoneksi serta berpartisipasi aktif dalam pembangunan berbasis e-government saja. Tetapi sekaligus memposisikan kota Surabaya sebagai pioneer serta role model bagi pemerintah daerah lainnya di tanah air di dalam mewujudkan kota cyber.

\section{Kesimpulan}

Berdasarkan hasil pembahasan di bab sebelumnya tentang hasil temuan serta analisa penelitian tentang pelaksanaan program pelatihan TIK di Broadband Learning Center (BLC) pada periode tahun 2014-2015 yang dilaksanakan oleh Dinas Kominfo Pemkot Surabaya, maka dapat diperoleh beberapa kesimpulan. Bahwa Dinas Kominfo Pemkot Surabaya secara maksimal telah menyampaikan pesan kepada masyarakat kota Surabaya dengan tujuan agar mempunyai literasi internet yang bagus, dimana hal tersebut dilakukan melalui ajakan pelatihan TIK di BLC.

Diantara indikator yang menunjukkan tentang tersampaikannya pesan tersebut dapat dilihat dari semakin banyaknya masyarakat kota Surabaya yang memanfaatkan BLC sebagai media pembelajaran TIK. Seperti yang terpantau dari hasil rekap data jumlah peserta pelatihan TIK di BLC pada tahun 2015 dengan interval waktu yang sama, terhitung mulai bulan Januari sampai April. Adanya peningkatan jumlah peserta dan pengunjung BLC tersebut mengindikasikan bahwa masyarakat kota Surabaya merespon pelaksanaan program dengan baik. Hal itu ditunjukkan melalui tingginya antusiasme belajar mereka pada saat mengikuti pelatihan TIK di BLC.

Dalam penelitian ini terungkap bahwa Dinas Kominfo bersama jajaran tim tenaga pengajar (instruktur) BLC berperan sebagai penggerak komunitas dengan memberikan stimuli serta mengajak masyarakat kota Surabaya agar mau belajar TIK. Tujuannya menjadikan warga melek IT secara keseluruhan, sehingga dapat mewujudkan Cyber Societyyang benar-benar smart. Tidak hanya cukup sampai pada fase pemahaman dan penguasaan TIK saja, melainkan mendorong masyarakat agar mampu memanfaatkan teknologi informasi untuk memenuhi kebutuhan hidupnya. 
Penerapan dan pengembangan konsep gyber city sebagai hasil penetrasi program BLC oleh Dinas Kominfo Pemkot Surabaya tersebut pada akhirnya akan meningkatkan kualitas sistem pemerintahan berbasis e-government yang selama ini telah dilaksanakan.

Berdasarkan data empiris yang terungkap pada bab sebelumnya diketahui bahwa program BLC masih belum dapat menjangkau semua lapisan masyarakat kota Surabaya, seperti yang ditargetkan oleh Dinas Kominfo Pemkot Surabaya selama ini. Sehingga, pelaksanaan program BLC yang diselenggarakan oleh Dinas Kominfo Pemkot Surabaya pada periode 2014 sampai bulan April 2015, masih terdapat beberapa hal yang masih harus diperbaiki ke depannya.

Dari segi ketersediaan infrastruktur diketahui bahwa sebagian besar masyarakat masih belum familiar dengan software Linux yang digunakan dalam program BLC. Hasil wawancara yang dilakukan dalam kegiatan Forum Group Discussion (FGD) pada tanggal 11 Maret 2015 lalu diketahui bahwa hampir semua peserta menyatakan ketidaktahuannya tentang sistem operasi komputer Linux yang digunakan dalam program BLC. Hal ini karena mereka telah terbiasa menggunakan Windows. Padahal, syarat utama dari efektifitas sebuah program pelatihan TIK adalah bagaimana caranya agar masyarakat dapat memanfaatkan hasil pelatihannya untuk dioperasikan dalam kehidupan sehari-hari diluar dari kelas pelatihan.

Di sisi lain, kegiatan publikasi tentang program BLC belum maksimal, karena sampai saat ini upaya sosialisasi untuk mempromosikan program BLC masih kurang intens. Padahal seharusnya, fasilitas pelatihan TIK yang ditujukan bagi terwujudnya literasi internet masyarakat kota Surabaya tersebut wajib diketahui oleh semua lapisan masyarakat, tanpa terkecuali.

\section{Ucapan Terimakasih}

Pelaksanaan Program Broadband Learning Center (BLC) Oleh Dinas Kominfo Pemkot Surabaya merupakanpenelitian yang mengungkapkan tentang bagaimana upaya manajemen komunikasi yang dilakukan oleh Dinas Kominfo Pemkot Surabaya untuk mereduksi kesenjangan digital (digital divide) di kota Surabaya melalui program pelatihan TIK bernama Broadband Learning Center (BLC). Tujuannya adalah menjadikan seluruh masyarakat kota Surabaya memiliki literasi internet yang 
bagus. Tidak hanya sekedar membuat mereka agar melek IT, tetapi juga dapat memanfaatkannya untuk memenuhi kebutuhannya, terutama dalam hal akses pelayanan publik di Pemkot Surabaya yang saat ini dilakukan secara digital/ $e$ government.

Setelah melakukan serangkaian penggalian data melalui Forum Group Discussion (FGD), wawancara \& observasi, penelitian tentang pelaksanaan program BLC ini telah dipertanggungjawabkan di hadapan penguji pada tanggal 15 September 2015. Untuk itu penulis sangat berterimakasih kepada pihak-pihak yang membantu dalam penyusunan artikel ini:

1. Ibu Antiek Sugiharti Kepala Dinas Komunikasi dan Informatika Pemkot Surabaya beserta jajarannya yang selalu memberikan waktu serta dukungannya selama penulis melakukan serangkaian penggalian data untuk kebutuhan tesis di sela jam kantor yang sangat padat. Baik data primer maupun data sekunder.

2. Tim BLC Taman Prestasi, Rumah Bahasa \& BLC Rusun Grudo yang terus mengup grade kemampuan TIK dan manajemen micro teaching-nya agar bisa memberikan pelatihan TIK berkualitas bagi masyarakat Surabaya.

3. Para peserta pelatihan TIK yang menjadi peserta FGD yang begitu luar biasa semangat \& spirit belajarnya di BLC Taman Prestasi. Terimakasih telah menularkan semangat pembelajar yang tak kenal lelah dalam menimba ilmu. Terutama Ibu Shinta, peserta program BLC yang selalu bersemangat belajar internet, meskipun beliau telah berusia 70 tahun.

4. Bapak Rudiantara Menteri Komunikasi dan Informatika yang telah meluangkan waktunya untuk diwawancarai penulis pada saat event Techno Fair 2015 yang bertempat di Universitas Gadjah Mada.

5. Para ahli IT, Mas Erwin \& Mas Budiono dengan sharing\& diskusi tentang tren serta aplikasi program pelatihan TIK-nya yang selalu melahirkan ide-ide baru yang selalu out of the box.

\section{Daftar Pustaka}

Baran, Stanley J. (2009). Mass Communication Theory: Foundations Ferment and Future. Singapore: Cengange Learning Asia.

Bungin, Burhan. (2006). Sosiologi Komunikasi. Jakarta: CV Rajawali. 
Denzin, Norman K dan Lincoln, Yvonna S. (2009). Handbook of Qualitative Research. Yogyakarta: Pustaka Pelajar.

Dwiyanto, Agus (Ed). (2008). Mewnjudkan Good Governance Melalui Pelayanan Publik: Cetakan Revisi 3. Yoyakarta: Gadjah Mada University Press.

Flew, Terry. (2002). New Media, An Introduction 2ND Edition. UK: Oxford University Press.

Indah Wahyuni, Hermin. (2013). Kebijakan Media Baru Di Indonesia. Yogyakarta: Gadjah Mada University Press.

Van Dijk, Jan A.G.M. (2006). The Network Society. London: Sage Publications.

Kellner, Douglas. (2000). Habermas, The Public Sphere, and Democracy: A Critical Intervention. IIlinois: Open Court Publishing.

Kriyantono, Rachmat. (2006). Teknik Praktis Riset Komunikasi. Jakarta: Kencana Prenada Media Group.

Komninous. Nicos. (2002). Intelligent Cities and Globalisation of Innovation Networks, London and New York: Routledge.

McQuail, Denis. (2010). Mass Communication Theory, 6 ed. Singapore: Sage Publications Asia-Pasific.

Mulyana, Deddy. (2007). Metodologi Penelitian Kualitatif. Bandung: PT remaja Rosdakarya.

Holmes, David. (2007). Communication Theory: Media, Technology \& Society. London: Sage Publication Ltd.

Indrajit, Richardus Eko. (2002). Electronic Government. Yogyakarta: Andi.

Indrajit, Richardus Eko. (2006). Manajemen Perguruan Tinggi Modern. Yogyakarta: Andi.

Ngurah Putra, I Gusti. (2008). Komunikasi Dan Politik, Sebuah Kajian Kritis. Yogyakarta: Fisipol UGM.

Patricia, Pascual J. (2003). E-Government: e-Primers for The Informations Economy Society and Policy. UNDP Asia Pasific.

Pavlik, John V. (1998). New Media Technology, Cultural and Commercial Perspectives. New York: Colombia University.

Rogers, Everett M. (1986). Communication Technology, The New Media In Society. New York: Collier Macmillan Publisher. 
Rules, William. (2007). The Case Study Handbook: How to Road, Discuss and Write Persuasively About Cases. Boston: Havard Business Press.

Rosady, Ruslan. (2002). Manajemen Humas \& Komunikasi, Konsep dan Aplikasi. Jakarta: PT Raja Grafindo Persada.

Sugiyono. (2008). Metode Penelitian Kuantitatif, Kualitatif dan R\&D. Bandung: Alfabeta. Sulistyowati, Fadjarini dan Setyowati, Yuli. 2005. Komunikasi Pemberdayaan. Yogyakarta: Program Studi Ilmu Komunikasi STPMD “APMD” dan APMD Press.

Suyanto, Bagong. (2006). Metode Penelitian Sosial. Jakarta: Kencana.

Yin, Robert K. (1989). Case Study Research Design and Method: Volume 5. London: Sage Publications, Inc.

\section{Jurnal \& Website}

Angelidou, Margarita. (2015). Smart City Strategy: New York (USA). Urban and Regional Innovation Research. http://www.urenio.org/2015/03/19/smart-city-strategy-new-york-usa/ (Diakses pada tanggal 5 Agustus 2015)

Aries, Erna Febru. (2008). Metode Penelitian Studi Kasus. http://ardhana12.wordpress.com/. (Diakses tanggal 5 September 2014)

BLC Surabaya Blogspot. (2014). Kegiatan BLC.http://blcsurabaya.blogspot.com/2014/02/kegiatan-blc.html (Diakses pada tanggal 4 Februari 2015)

BLC Surabaya Blogspot. (2014). Info Pembelajaran.http://blcsurabaya.blogspot.com/2014/02/infopembelajaran.html (Diakses pada tanggal 4 Februari 2015)

Damanik, Marudur P. (2012). Literasi Internet Masyarakat Dalam Implementasi Pelayanan Publik Berbasis E-Government Di Kabupaten Deli Serdang Provinsi Sumatra $\begin{array}{lllll}\text { Utara. } & \text { Widyariset, } & \text { Vol. } & 15 & \text { No. }\end{array}$ http://widyariset.pusbindiklat.lipi.go.id/index.php/widyariset/article/vie wFile/25/20 (Diakses pada tanggal 2 Januari 2015)

http:/ / digilib.unila.ac.id/4640/19/Bab\%20II.pdf

http://dispendukcapil.surabaya.go.id/index.php 
Djumadal, J. Surat. (2008). Implementasi e-Government. Sebuah Harapan Penub Tantangan Di Propinci Daerah Istimewa Yogyakarta. Proceeding Konferensi dan Temu Nasional Teknologi Informasi dan Komunikasi Untuk Indonesia. http://iatt.kemenperin.go.id/tik/fullpaper/fullpaper152.pdf (Diakses pada tanggal 2 Januari 2015)

Elly, Muhammad Jafar. (2008). Mewujudkan Cyber City Di Indonesia. www.biskom.web.id/2008/07/02/mewujudkan-cyber-city-diindonesia.bwi(Diakses pada tanggal 2 Maret 2015)

Fahmiarto, Anjar. (2014). Kecepatan Dan Pemerataan Internet Jadi PR Besar.http://www.republika.co.id/berita/koran/trentek/14/10/31/neau 8a8-kecepatan-dan-pemerataan-internet-jadi-pr-besar

Fang, Zhingyuan. (2002). E-Government in Digital Era: Concept, Practice, and Development. International Journal of The Computer, The Internet and Management.http://unpan1.un.org/intradoc/groups/public/documents /apcity/unpan016377.pdf (Diakses pada tanggal 7 Maret 2015)

Jolls, Tessa. (2011). Interview Script of James Potter. http://www.medialit.org/sites/default/files/Voices_of_ML_\%20James _Potter.pdf (Diakses pada tanggal 19 Agustus 2015)

Prihanto. (2013). http://balitbang.kominfo.go.id/balitbang/bppkiyogyakarta/files/2014/04/05_Artikel-_Igf Prihanto_des_2013.pdf (Diakses pada tanggal 2 Maret 2015)

Indrajit, RE. Strategi Membangun Smart City. (2012). Referensi BNSP. www.bnsp.go.id/assets/.../Ekoji999-Edisi001-9Sep12-SmartCity_0.pdf (Diakses pada tanggal 13 Desember 2014)

Karman, Karman. (2012). Pola Penggunaan Media Digital Di Kalangan Anak Dan Remaja (Kasus di Kota Jayapura Propinsi Papua). Jurnal Penelitian Pos Dan Informatika. http://jurnal.kominfo.go.id/index.php/jppi (Diakses pada tanggal 28 Juli 2015)

Komninos, Nicos. (2015). Citizen-Driven Innovation and Smart Cities. Urban and Regional Innovation Research. http://www.urenio.org/2015/06/20/citizen-driven-innovation-andsmart-cities/ (Diakses pada tanggal 5 Agustus 2015) 
Kozma, Robert B. (1991). Learning With Media. Review of Educational Research.http://robertkozma.com/images/kozma_rer.pdf (Diakses pada tanggal 9 Nopember 2014)

Livingstone, Sonia. (2008). Internet Literacy: Young People's Negotiation of New Online Opportunities. Digital Youth, Innovation and Unexpected - Internet Literacy Handbook. http://core.ac.uk/download/pdf/93540.pdf (Diakses pada tanggal 5 Agustus 2015)

Masyhur, Firdaus. (2014). Kesiapan e-Skills Pemerintah Daerah Dalam Implementasi eGovernment Di Kawasan Mamminasata. Jurnal Penelitian Komunikasi, Informatika Dan Media Massa.http://jurnal.kominfo.go.id/index.php/pekommas/article/view/ 210 (Diakses pada tanggal 4 Agustus 2015)

Meiningsih, Siti. (2011). Kajian Indikator TIK Indonesia: Pola Akses dan Penggunaan TIK Oleh Rumah Tangga dan Individu. Jurnal Penelitian Pos Dan Informatika. http://publikasi.kominfo.go.id/bitstream/handle/54323613/837/Jurnal \%20PPI-Volume1-2011.pdf?sequence $=1$ (Diakses pada tanggal 9 Nopember 2014)

Mudjiyanto, Bambang. (2012). Literasi Internet dan Partisipasi Politik Masyarakat Pemilih Dalam Aktivitas Pemanfaatan Media Baru. Jurnal Studi Komunikasi dan Media. http://jurnal.kominfo.go.id/index.php/jskm/article/view/2/24 (Diakses pada tanggal 3 Januari 2015)

Muhammad, Sholihuddin. (2014). Pengarub Kompetensi Individu Terbadap Literasi Media Internet Di Kalangan Santri.http://journal.unair.ac.id/filerPDF/ln05697e9fb4full.pdf (Diakses pada tanggal 19 Agustus 2015)

Panagiotis Tsarchopoulus. (2015). Report: Rethinking Smart Cities From The Ground Up. Urban and Regional Innovation Research. http:/ / www.urenio.org/2015/06/24/report-rethinking-smart-citiesfrom-the-ground-up/\#more-11461 (Diakses pada tanggal 5 Agustus 2015)

Putro, Arif Suryanto. (2011). Tinjauan Pemanfaatan Internet Sehat Pada Masyarakat di Kota Yogyakarta. Jurnal Penelitian Pos Dan Informatika. 
http://publikasi.kominfo.go.id/bitstream/handle/54323613/837/Jurnal \%20PPI-Volume1-2011.pdf?sequence $=1$ (Diakses pada tanggal 9 Nopember 2014)

Rao, Kailasa \& Sravanthi. (2012). E-Governance Web Services For Web Seniors. International Journal Of Computational Engineering Research $\begin{array}{lllll}\text { (ijceronline.com) } & \text { Vol. } & 2 & \text { Issue. } & 5 .\end{array}$ http://www.ijceronline.com/papers/Vol2_issue5/CD02516561659.pdf (Diakses pada tanggal 4 Agustus 2015)

Sekar, S.P. Marching Towards Cyber City-A Planning Perspective.http://www.unesco.org/most/isocarp/proceedings2001/cases /cs01_1238/spsekar.htm (Diakses pada tanggal 2 Maret 2015)

Simamora, Nani Grace. Ketertarikan Masyarakat Dalam Mengakses Informasi IPTEK Dengan Menggunakan Media kominfo: Tinjauan Empirik. Jurnal Penelitian Pos dan Informatika. https://publikasi.kominfo.go.id/bitstream/handle/54323613/837/Jurna 1\%20PPI-Volume1-2011.pdf?sequence $=1$ \&isAllowed $=y$ (Diakses pada tanggal 4 Agustus 2014)

Susanto, Anton. (2011). Pengujian Technology Acceptance Model Pada Pusat Layanan Internet Kecamatan (PLIK). Jurnal Penelitian Pos Dan Informatika. http://publikasi.kominfo.go.id/bitstream/handle/54323613/837/Jurnal \%20PPI-Volume1-2011.pdf?sequence=1 (Diakses pada tanggal 9 Nopember 2014)

Surya, Iman \& Sangkala. (2015). Electronic Government In Democratic Public Service In One Door Integrated Permit Handling Services Agency In The City Of City Of Samarinda. International Journal of Scientific \& Technology Research. http://www.ijstr.org/paper-references.php?ref=IJSTR-0115-10829

(Diakses pada tanggal 4 Agustus 2015)

Suharto, Totok. (2010). Pengembangan Sumberdaya Aparatur Dalam Digital Govenrment Service: Siapkah Dikelola Sendiri? http://totoksuharto.blogspot.com/2010/02/pengembangansumberdaya-aparatur-dalam.html (Diakses pada tanggal 7 Maret 2015) 
Suharto, Totok. (2010). Pelayanan Publik Dalam Era Otonomi Daerah.http://totoksuharto.blogspot.com/2010/02/pengembangansumberdaya-aparatur-dalam.html (Diakses pada tanggal 7 Maret 2015)

Suharto, Totok. (2010). Pengembangan Kapasitas Aparatur Pemerintah Daerah. http://totoksuharto.blogspot.com/2010/02/pengembangansumberdaya-aparatur-dalam.html (Diakses pada tanggal 7 Maret 2015) Van Dijk, Jan A.G.M. (2012). The Evolution of the Digital Divide The Digital Divide Turns to Inequality of Skills and Usage.www.utwente.nl/.../vandijk/.../The\%20Evolution (Diakses pada tanggal 19 Agustus 2015).

Kementerian Kominfo. (2013). Open Source Di Kominfo. http://kominfo.go.id/index.php/content/detail/3434/Open+Source+d i+Kominfo/0/program_prioritas\#.VcKAyv5jd1Q (Diakses pada tanggal 3 Maret 2015)

Kementerian Kominfo. (2013). Aplikasi e-Government. http://kominfo.go.id/index.php/content/detail/3319/Aplikasi+egovernment/0/e_government\#.VcKGXf5jd1Q (Diakses pada tanggal 3 Maret 2015)

Kementerian Kominfo. (2013). Kominfo: Pengguna Internet Di Indonesia 63 Juta Orang.http://kominfo.go.id/index.php/content/detail/3415/Kominfo+ $\% 3 \mathrm{~A}+$ Pengguna+Internet+di+Indonesia $+63+$ Juta+Orang/0/berita_sat ker\#.VcKNsv5jd1Q (Diakses pada tanggal 5 Maret 2015)

Kementerian Kominfo. (2013). Data Center e-Government. http://kominfo.go.id/index.php/content/detail/3320/Data+Center+eGovernment/0/e_government\#.VcKJJP5jd1Q (Diakses pada tanggal 4 Maret 2015)

Kementerian Kominfo. (2013). Balitbang SDM Kominfo Adakan Sertifikasi SDM TIK.http://kominfo.go.id/index.php/content/detail/1464/Balitbang+S $\mathrm{DM}+$ Kominfo+Adakan+Sertifikasi+SDM+TIK/0/berita_satker\#.VcK OJP5jd1Q (Diakses pada tanggal 4 Maret 2015) 
Kementerian Kominfo. (2014). Buku Putih TIK Kominfo 2013.https://balitbang.kominfo.go.id/ppi/?p=443 (Diakses pada tanggal 5 Agustus 2015)

Kementerian Kominfo. (2015). Workshop Smart Community for Smart City.https://balitbang.kominfo.go.id/ppi/?p=585 (Diakses pada tanggal 5 Agustus 2015)

Pemkot Surabaya. Broadband Learning Center (BLC).(2013). http://www.surabaya.go.id/dinamis/?id=5442 (Diakses pada tanggal 15 Desember 2014)

Pemkot Surabaya. (2013). Media Center Pemerintah Kota Surabaya.http://www.surabaya.go.id/ver5/?vID=10 (Diakses pada tanggal 16 Maret 2015)

Pemkot Surabaya. (2013). Daftar Lokasi Pelayanan e-Kios Pemerintah Kota Surabaya. http://www.surabaya.go.id/dinamis/?id=5941 (Diakses pada tanggal 16 Maret 2015)

$\begin{array}{llll}\text { Pemkot Surabaya. (2013). Surabaya Single Window. } & \text { S }\end{array}$ http://ssw.surabaya.go.id/index.php?hal=subijin\&kd_ijin=170000\&kd_ paket $=\& k d \_s k p d=\& k d \_i j i n \_e x t=($ Diakses pada tanggal 16 Maret 2015)

Dinas Kominfo Pemkot Surabaya. (2013). Menteri Kominfo: Broadband Mampu Mendorong Pengembangan

Teknologi.http:/ / dinkominfo.surabaya.go.id/dki.php?hal=100\&id=116

(Diakses pada tanggal 15 Februari 2015)

Dinas Kominfo Pemkot Surabaya. (2013). Pelayanan Informasi Komunikasi Publik Melalui Media Center.http:/ / dinkominfo.surabaya.go.id/dki.php?hal=100\&id=103

(Diakses pada tanggal 15 Februari 2015)

Dinas Komunikasi Pemkot Surabaya. (2013). Etika dan Ketentuan Dalam Dunia TIK.http:/ / dinkominfo.surabaya.go.id/dki.php?hal=100\&id=104 (Diakses pada tanggal 15 Februari 2015)

Dinas Komunikasi Pemkot Surabaya. (2013). Manfaat Teknologi Informasi dan Komunikasi Dalam 
Pendidikan.http:/ / dinkominfo.surabaya.go.id/dki.php?hal=100\&id=75

(Diakses pada tanggal 16 Februari 2015)

Dinas Kominfo Pemkot Surabaya. (2013). Kota Surabaya Raib FuturGov Award. http://dinkominfo.surabaya.go.id/dki.php?hal=detail_berita\&id_berita= 192 (Diakses pada tanggal 16 Maret 2015)

Dinas Kominfo Pemkot Surabaya. (2013). Surabaya Raih Juara Indonesia Digital Society Award 2013. http://dinkominfo.surabaya.go.id/dki.php?hal=detail_berita\&id_berita= 190 (Diakses pada tanggal 16 Maret 2015)

Dinas Kominfo Pemkot Surabaya. (2013). Kunjungan Vice President IBM Dalam rangka Memahami Penggunaan TI Di Pemerintah Kota Surabaya. http://dinkominfo.surabaya.go.id/dki.php?hal=detail_berita\&id_berita= 186 (Diakses pada tanggal 16 Maret 2015)

Dinas Kominfo Pemkot Surabaya. (2013). Surabaya Single Window (SSW). http://dinkominfo.surabaya.go.id/dki.php?hal=detail_berita\&id_berita= 178\&auth=2 (Diakses pada tanggal 16 Maret 2015)

Pemkot Surabaya. (2013). Perijinan Online Kota Surabaya. http://dinkominfo.surabaya.go.id/dki.php?hal=detail_berita\&id_berita= 43\&auth=2 (Diakses pada tanggal 16 Maret 2015)

Dinas Kominfo Pemkot Surabaya. (2013). Jaringan Pemerintah Kota.http://dinkominfo.surabaya.go.id/dki.php?hal=detail_berita\&id_be rita $=41 \&$ auth $=2$ (Diakses pada tanggal 16 Maret 2015)

Dinas Kominfo Pemkot Surabaya. (2013). Pelayanan Perijinan. http://ssw.surabaya.go.id/index.php?hal=subijin\&kd_ijin=170000\&kd_ paket $=\& k d \_s k p d=\& k d \_i j i n \_e x t($ Diakses pada tanggal 16 Maret 2015)

Dinas Kominfo Pemkot Surabaya. (2012). Profil Dinas Komunikasi dan Informatika.http://dinkominfo.surabaya.go.id/dki.php?hal=1 (Diakses pada tanggal 4 Februari 2015)

Dinas Kominfo Pemkot Surabaya. (2012). Struktur Organisasi.http://dinkominfo.surabaya.go.id/dki.php?hal=8 (Diakses pada tanggal 4 Februari 2015) 
Dinas Kominfo Pemkot Surabaya. (2012). Sejarah Dinkominfo. http://dinkominfo.surabaya.go.id/dki.php?hal=6 (Diakses pada tanggal 5 Februari 2015)

Dinas Kominfo Pemkot Surabaya. (2012). Visi Misi. http://dinkominfo.surabaya.go.id/dki.php?hal=7 (Diakses pada tanggal 5 Februari 2015)

Dinas Kominfo Pemkot Surabaya. (2012). Daftar Nama Pegawai Dinkominfo Surabaya. http://dinkominfo.surabaya.go.id/dki.php?hal=9 (Diakses pada tanggal 5 Februari 2015)

Dinas Kominfo Pemkot Surabaya. (2012). Rincian Tugas \& Fungsi Dinkominfo Surabaya. http://dinkominfo.surabaya.go.id/dki.php?hal=10 (Diakses pada tanggal 5 Februari 2015)

Pemprov Bali. (2012). E-Government Dalam Transparansi Sistem Pemerintahan Modern. http://www.biropem.baliprov.go.id/id/E-Government-DalamTransparansi--Sistem-Pemerintahan-Modern-(Diakses pada tanggal 5 Februari 2015)

Kompas. (2015). Lima Bekal Kecakapan Majukan Perekonomian Berbasis Digital. http://bisniskeuangan.kompas.com/read/2015/05/04/204121626/Lim a.Bekal.Kecakapan.Majukan.Perekonomian.Berbasis.Informasi. (Diakses pada tanggal 5 Agustus 2015)

Republika. (2015). Pemkot Depok Wujudkan Kota Cyber City.http://www.republika.co.id/berita/nasional/jabodetabeknasional/15/06/13/npw1yj-pemkot-depok-wujudkan-kota-emcybercityem(Diakses pada tanggal 5 Agustus 2015)

\section{Perundangan dan Dokumen}

Undang-Undang No 32 Tahun 2004 Tentang Pemerintah Daerah

Undang-Undang No 14 Tahun 2008 Tentang Keterbukaan Informasi Publik

Peraturan Walikota Surabaya No 5 Tahun 2013 Tentang Pedoman Pemanfaatan Teknologi Informasi Dan Komunikasi

Inpres No 3 Tahun 2003 Tentang Kebijakan \& Strategi Nasional Pengembangan $e$ Government. 
https://ppidkemkominfo.files.wordpress.com/2012/12/instruksi_presid en_no_3_th_20031.pdf (Diakses pada tanggal 5 Agustus 2015)

Inpres No 6 tahun 2001 Tentang Pengembangan \& Pendayagunaan Telematika di Indonesia.

https://ppidkemkominfo.files.wordpress.com/2012/12/inpres-no-6tahun-20011.pdf (Diakses pada tanggal 5 Agustus 2015)

Permen Kominfo No 19 tahun 2010 Tentang Perubahan Atas Menteri Kominfo No 48 tahun 2009 Tentang Penyediaan Jasa Akses Internet Pada Wilayah Pelayanan Universal Telekomunikasi Internet Kecamatan. http://dittel.kominfo.go.id/wp-content/uploads/2013/06/PM-192010.pdf (Diakses pada tanggal 5 Agustus 2015)

Permen Kominfo No 20 Tahun 2010 Tentang Sistem Informasi Manajemen \& Monitoring Internet Kayanan Kecamatan. http:/ / dittel.kominfo.go.id/wp-content/uploads/2013/06/PM-202010.pdf (Diakses pada tanggal 5 Agustus 2015)

Permen Kominfo No 21 Tahun 2010 Tentang Penyediaan Nusantara Internet Exchange Untuk Layanan Internet Pada Wilayah Pelayanan Universal Telekomunikasi Internet Kecamatan. http://dittel.kominfo.go.id/wpcontent/uploads/2013/06/PM-21-2010.pdf (Diakses pada tanggal 5 Agustus 2015) 